\title{
The gift of repentance: a Maussian perspective on twenty years of pentimento in Italy
}

\section{Introduction}

I N M A Y I999 one of Italy's senior postwar politicians, Giulio Andreotti, was waiting for courts in Perugia and Palermo to hand down their verdicts on the charges of murder and mafia affiliation brought against him on the basis of the testimony of eight former mafiosi. At the same time, three erstwhile members of the long-dissolved extraparliamentary Left group Lotta Continua, were waiting for the Court of Cassation in Rome to hand down its latest decision in an apparently interminable sequence of judicial disputes on whether the confession by a fellow former member of the group could justify their convictions for the murder of the police officer Luigi Calabresi in 1972. Meanwhile, in Milan, the judicial system continued to work through the ramifying investigations of the Tangentopoli corruption scandal, helped by the full confession of a local Socialist Party politician in I 992 (I). In all three cases, therefore, the key evidence for the charges brought by prosecutors came from the testimony of pentiti-literally, 'those who have repented' - who had turned state's evidence in return for the promise of reduced sentences and other benefits and had thus embarked on the sequence of exchanges I shall refer to as pentimento (2).

(I) Details of these cases can be found in Lupo (1996), Biacchessi (r998) and Andreoli (I993).

(2) The term 'pentiti' was at once controversial because of its implication that repentance and remorse necessarily accompanied confession. To avoid that implication, Italian legislators and prosecutors prefer 'collaborator with the judicial system' (collaboratore della giustizia), a phrase which leaves open both the motivation and the extent of the collaboration. However, because 'pentiti' is by now firmly established and its English equivalents are cumbersome or imprecise, I shall use the Italian term. 
As those cases indicate, the practice of secular confession has shed quite unexpectedly strong light on some of the darker sides of postwar Italian politics and society. Indeed, as the strategy of rewarding confessions has been extended, pentiti have come forward in increasing numbers: by the late I 990 s more than five thousand collaborators and their families were under police protection and an association defending their image and interests had been launched (Ormanni i 999: 85). Some have become, if not quite celebrities, certainly household names, appearing on television and summoned as experts by Parliament and the press to explain developments in the types of violence they have renounced. Moreover, their role in helping to dismantle political violence and organised crime has led to the imitation of the Italian measures to encourage confessions by several other European countries (Vercher I 992; Greer I995). Yet, despite its practical and cultural significance, pentimento has attracted far more polemics than analyses: detailed studies have been largely confined to technical jurisprudential commentaries on specific features of single laws. The contents of the confessions have certainly become indispensable for writing-usually rewriting-the histories of political violence, mafia and corruption (e.g. Gambetta I993). But the practice of confession itself-the rules and relationships through which those contents have been elicited, shaped and given the imprimatur of reliable historical evidence-has been more or less ignored.

Little analytical help in undertaking this task is available from the contemporary social sciences. Anthropological attention has mostly been devoted to social and historical contexts remote from contemporary Europe and the once intense interest in witchcraft confessions seems to have disappeared along with the functionalist framework in which the analyses were often conducted (Douglas I970). A similar sense of distance also characterises the historical and sociological study of the show-trials and public confessions of the Soviet era, although the recent opening of the regime's archives may renew interest (Getty I 999). Even Foucault's efforts to give confessional technologies a place at the centre of contemporary social discipline have not produced more than an occasional empirical study (e.g. Hepworth and Turner I982), perhaps because the distinctiveness of the practices which are explicitly confessional has been submerged in the assertion of a ubiquitous but analytically elusive confessionality.

Long before Foucault, however, Marcel Mauss had described confession as 'un des principaux organes de discipline et de domination', linked by repentance and absolution 'à toute l'organisation morale de 
nos sociétés occidentales' (I903: 64I-2). His interest in the topic was encouraged by collaboration with Robert Hertz and reliance on Hertz's materials on sin, confession and expiation in his teaching at the Collège de France (Hertz i 996 [1922]; Jamin and Lupu ı 987; Parkin ı996). As part of their joint interest in exchange-it was Hertz who signalled to Mauss the importance of Elsdon Best's report of Ranapiri's famous text on the hau of Maori gifts (Mauss I990: IO-II)-they interpreted confession, repentance and pardon as integral elements in the expiatory exchanges which followed injuries and offences. Although Mauss does not seem anywhere to have explicitly characterised confession as a type of exchange, he certainly regarded words as exchange items of equal significance to material objects in the creation of social order (Caillé i 996: I 86; Jamous i 999: 294). Indeed, it was the French copyright law of 1923 that he selected as his principal contemporary example of the continuing connection between persons and their products (Mauss I 990: 67). Licence can therefore be found in Mauss' own writings for an approach to confessions which treats them as valuables in a system of exchanges and analyses their organisation in some of the same descriptive terms used for the institutions of the kula and potlatch.

Taking that approach to pentimento offers an opportunity to develop Mauss' own insights in various directions. First, it enables us to explore their application to the very area which he regarded as the principal justification of his own interest in gifts: the deliberate creation of exchanges to prevent violence and maintain peace. The frequency of references to violence, chicanery and mistrust in the Essay on the Gift has often been pointed out; the connection is underlined even more strongly if we note that while he was writing the Essay, Mauss was also devoting himself to the analysis of Bolshevik and Fascist violence ( 997 [ 1 923-4]: 509-566). Second, examining the case of pentimento as a type of giftexchange encourages us to continue broadening the study of gifts beyond the economic and commodity contexts which have been central to most discussions of the enduring relevance of his work (Davis r 992; Allen and James I 998; Barbrook I999; Godelier I 999). The kind of extension illustrated by Stirrat and Henkel (I997), who use Mauss' analysis of gifts to characterise the linkages between contemporary development organisations in the distribution of aid, reinforces Karsenti's point that the principle of the gift can be embodied in many different social forms and practices ( I 994: 9). Third, the very recency of pentimento provides a rather rare opportunity to track in detail the creation and evolution of a particular exchange relationship and identify the pressures responsible for its modifications. The rules about who is to be admitted to the 
exchange, what value the confession is to have and how it is to be received and reciprocated have to be established through public discussion and justification as the exchange itself develops; they cannot be treated as mere matters of social custom (3). Finally, adding secular confessions to the list of valuables classifiable as gifts invites us also to examine how far the substantive characteristics of the raw materials used as gifts-information, in the case of confessions-help in themselves to shape the trajectories and relationships through which they are transmitted. Like information, many contemporary gift-items (blood, semen, philanthropic donations) can be fragmented, recombined and dispersed more easily than seems to have been possible for the armshells, necklaces and coppers which made up the classical gifts in the kula and potlatch. Emphasis on the partibility of the giver has been a central issue in recent analyses of Melanesian exchange (Strathern I988); but it is the partibility of the gift, and the implications for relations among participants, which emerges as a matter of equal concern in the exchanges built around pentimento. Those more general issues will not be explored in what follows, but perhaps the analysis of pentimento as an example of gift-exchange may encourage a similar approach to other kinds of contemporary transaction.

\section{Pentimento as a total social fact (4)}

\section{The legal foundations}

The basic model of pentimento was established in December I 979 when, at the end of the worst year for political violence in the decade, the Italian government introduced decree 625/1979, converted into law I 5/I 980 the following February, which offered a substantial reduction in sentence to anyone charged with crimes of terrorism or subversion who turned state's evidence. Obtaining the reduction required a full confession, unequivocal rupture of all contact with terrorist organisations and active collaboration in identifying former accomplices and averting

(3) Firth (1967: I I) stresses that, against the impression Mauss conveys, significant areas of choice and uncertainty on the receiving and reciprocating of gifts existed even in the societies described in The Gift.
(4) For the definition and illustration of a 'total social fact' see Mauss (I990: 38, 79). Karsenti (I997) and Gofman (I998) provide recent exegeses. 
further violence. If a confession enabled police and magistrates to gather 'decisive proof' to incriminate conspirators, its author was entitled to a reduction of between one-third and one-half of the normal prison term: the penalty for murder could be reduced from life imprisonment to a sentence of between twelve and twenty years. The incentive to confess was redoubled by the simultaneous introduction of draconian increases in the penalties for political violence: mandatory arrest, elimination of bail, extension to the maximum permissible duration of pre-trial custody, and harsher sentences.

Pentimento was not of course entirely new. It wove together elements already present in the penal code and-as the term 'repentance' makes obvious-in the rites of Catholic confession. On the legal side, defection from a political conspiracy before any offence had actually been committed already entailed no penalty; and, following the kidnapping of Aldo Moro in 1978 , a substantial reduction in sentence for political kidnappers who turned themselves in and helped get the hostage freed had also been introduced (5). Before I979, however, the benefits of collaboration were directly conditional on practical results-preventing the illegal activities for which the group had been formed or repairing the damage already caused. Law i 5/ i 980 contained two innovations. First, it widened the pool of exchangers from kidnappers to anyone belonging to an armed group whose actions were motivated by terrorism or subversion. Second, it demanded collaboration not just to avert a crime or reduce its effects but to identify and capture accomplices. In requiring a further verifiable rupture with 'armed struggle' by the explicit repudiation of violence and the past built around it, the law effectively insisted on a radical transformation of the exchanger's identity and social relations.

The resulting scrutiny of the pentito's state of mind, the obligation to recant publicly and the requirement to incriminate others led critics to denounce the regression of the Italian judicial system towards the model of the Inquisition and a dangerous confusion of legal, religious and moral considerations (Padovani I98 ; Prosperi I 997). Some features of pentimento are indeed shared with religious confession. Both are rites of reconciliation between people who have put themselves outside a community and the community's authorities. Both are designed to achieve the separation of actors from the consequences of their acts, sinners from their sins and political offenders from the ordinary penalties for their offences ( $c f$. Parkin I 996: I 40). Appropriate actions and attitudes are defined for participants, formulae are prescribed for successful

(5) Law no. I9 I, I 8 May I978, article 2. For a summary of the existing types of extenuating circumstances that could be pleaded, see Padovani ( I98 I). 
exchanges and confidentiality is imposed on the content of the confession. The structure of participation in both types of exchange is triadic: the priest mediates the transaction between sinner and God, the courts confer the benefits provided for pentiti by Parliament. But the equally striking differences between the two models make any straightforward identification misleading. Religious confession is oral; the exchange of confession for absolution is protected by anonymity; and the transaction is completed immediately. The model of secular pentimento envisaged by law I 5/I980 is significantly more complex on all three dimensions. First, confession is initially made orally but only acquires its full value when written down for use in court. In the second place, the risks entailed in turning state's evidence encourage pentiti to make the relationship with the recipients of their confessions as personal and enduring as possible. Thirdly, the reduction in sentence which completes the exchange is only made at an uncertain time in the future; the author of a confession is not guaranteed recognition of the status of pentito from the outset nor assured that the court will in fact complete the exchange or honour its terms. The two separations-the confession from its author and the deferral of reciprocation-thus ensure that all pentimento exchanges are risky and prolonged transactions, likely to be marked by contests which involve control over the path followed by the confession, the incorporation of subsidiary exchanges en route and the preservation of the integrity of the gift-confession itself.

Although the core of pentimento is a legally sanctioned exchange, it weaves together political, social, economic and moral ideas and institutions in the way that Mauss argued was typical of total social facts and which goes far beyond its limited overlap with the religious model of confession. Its principal objective is to defend a political system already dominated by other types of exchange relationships: 'bargained pluralism' between political parties and patronage within them (Hine I 993). To participate signals acceptance of the state's political and legal authority. Socially, the course of pentimento not only destroys relations among former comrades-in-arms but also creates dramatic encounters, confrontational or reconciliatory, between terrorists and their victims, and later between mafiosi and the politicians they accuse, drawing people from very different backgrounds into unpredictable and sometimes extended public collisions. Finally, the economic dimension of pentimento has also attracted increasing attention not only because of the material advantages that accrue to individual pentiti but also because of the rising burden on the public purse. The state pays for the legal defence of important pentiti, gives them a lump sum when they leave 
prison, provides a regular 'salary' for those who cannot work for security reasons, and covers the increasing costs of their protection inside and outside prison (6). The expense of protecting pentiti and changing their identities has become a significant element in decisions about whether to restrict or expand eligibility for the exchange. Moreover, the recently introduced requirement that candidates for recognition as genuine pentiti must provide detailed information on the wealth accrued from their crimes which can then be confiscated by the state has given the exchange an explicit economic dimension.

\section{Creating a valuable out of information}

Law i 5/I 980 converted insider knowledge about armed struggle into an item of exchange; and it is the specific characteristics of information as a commodity which therefore give the exchange many of its distinctive features. Within the armed groups themselves, information was already a scarce and highly valued resource, its circulation subject to various safeguards against the risk of police infiltration and its distribution roughly correlated with the organisational hierarchy. The more deeply-involved activists thus found themselves in possession of a store of valuables available for exchange with people hitherto defined as enemies. What the exchange-rate for such valuables might be was to be decided within the range between minimum and maximum sentences prescribed by the law: it was therefore indeterminate for both donor and recipient at the moment when the exchange was initiated.

The actual value of a confession is revealed progressively, according to the usefulness of its different elements to successive recipients. The first phase of the confession is usually the oral communication of information to police, who can immediately use it to arrest alleged accomplices and seize weapons. The second phase is initiated by embedding the information in a signed document (verbale) in front of the investigating magistrate for whom it is of critical value in building the case for the prosecution, bringing participants to court and securing their convictions. This phase can be prolonged: the confession which helped to dismantle the terrorist group Prima Linea, for example, took three months to complete (Genova I $985: 59$ ). However, for both the state and

(6) The early terrorist pentiti were given 20 million lire when they left prison; for state payment of defence expenses see Genova ( 1985 : 142). In 1997 the mafia pentito Balduccio di Maggio, responsible for the arrest of
Totò Riina and the incrimination of Andreotti, was given an advance payment of 500 million lire. The consequences of the increasing costs of protection are discussed below. 
former terrorists, the full value of a confession-respectively, obtaining convictions and securing a reduced sentence-is only realised at the conclusion of the trial, when verdict and sentence are handed down. In practice, several different judges and juries are likely to be involved since confessions contain details of multiple crimes which may have to be tried separately and sentences are usually appealed to two tiers of higher courts. Preserving the value of a confession over so varied and lengthy a scrutiny is a vital task for all parties (donors and recipients).

The delay in reciprocation of a confession underlines the importance of a well-known distinctive feature of information. Although it is passed on permanently to its recipient, it also remains in the possession of the donor. Givers and receivers are therefore doubly linked, not only by their shared possession of a piece of information (which will probably also be shared by others) but also by the more restricted knowledge that its transmission has taken place. Because of the incentive for people who discover that they have been named in a confession immediately to destroy evidence, evade arrest or retaliate against the pentito to prevent further revelations, this second-order information that information has been passed on is kept secret as long as possible. Even if some details are leaked or guessed, however, the actual scope of the confession will be known only to the giver and recipient. As long as the exchange remains to be completed in court, the giver and receiver are bound together in the joint effort to preserve its value: the prosecution is determined to secure convictions, the pentito to obtain the benefits envisaged by the law. Until the material can be formally made public at the end of the trial, its details and emphases can be revised, expanded and retracted by the donor who thus retains at least some hold over the content of the confession. It is thus the distinctive substance of information that gives a confession its hau: '[e]ven when it has been abandoned by the giver, it still possesses something of him' (Mauss I 990: I 2). Like a Maori gift, a confession binds together all subsequent recipients to whom it passes-which is why great care is taken by both donor and recipients to try to control its circulation.

The value of information in the hands of any single pentito is not, however, simply fixed by its practical utility or by its acceptability in court. It also has a clear market dimension: confessions immediately reduce the exchange value of the same information in the possession of others. Once police or judicial investigations have converted that information into knowledge, its value immediately declines to mere confirmation of another pentito's word and even to zero if accomplices have already been arrested or weapons seized. The emphasis in law i 5/80 on the practical results of confessions thus encourages would-be exchang- 
ers to search for further valuable information or to inflate the significance of what they possess, for example by describing the activities of fellow-conspirators in ways which may make them appear more deeply involved in armed struggle than they actually were. A further strategy, illustrated below, is to demand recognition of the value of a lesser gift, detached from immediate practical use. In these respects, pentimento offers a contemporary example of what Godelier, summarising Mauss, describes as the irresistible logic of the potlatch: 'once a system of agonistic gift-exchange is put in place... nothing seems capable of stopping it... [e]ach gift supposes, presupposes other gifts, in an endless chain that seems to be self-driven' ( I 999: 69-70).

\section{Confession as social deceit: freedom and obligation, altruism and self-interest}

Central to Mauss' analysis of gifts is his insistence on their powering by an inextricable mix of altruism and self-interest ( $1990: 3,73$ ). Here, in a similar vein, are some authoritative guidelines for the judicial scrutiny of confessions, emphasising their inevitable combination of spontaneity and disinterestedness: '[their] intrinsic reliability must be inferred from the directness, lack of ambiguity, the spontaneity and authenticity, and the consistency and logical coherence of the accusatory statements, from the absence not only of suggestions and conditioning by the investigators but also of any desire for the limelight, as well as from the disinterestedness displayed by the accuser, to be assessed in the light not only of any eventual indications of resentment, enmity and general motives of vendetta and revenge against the targets of the accusations but also of the hope of obtaining benefits...' (Court of Cassation, ist section, 22 January I996, sentence no. 683). The public advantage rested on confessions being motivated by a sincere and permanent detachment from violence. But the very effectiveness of the law in eliciting those confessions at all depended of course explicitly on the appeal to selfinterest among those who could earn a sentence reduction. A confession must therefore be the simultaneous product both of an unforced recognition that violence is fruitless or unacceptable and of the selfinterested concern to obtain a reduced sentence. But to achieve the maximum return, it must assume the guise of a 'free gift', concealing any origins in considerations of private gain, the desire for revenge or the impossibility of evading the overwhelming evidence of guilt.

In practice, confessions were only offered by people already in custody: no terrorists turned themselves in just to take advantage of the 
exchange. Under these circumstances it was much easier to ascribe their appearance to constraint and self-interest than to spontaneity and voluntariness. Indeed, the more rapid and complete the decision to collaborate, the more likely is its interpretation as a strategic route to the reduction of an inevitable prison sentence rather than as a genuine repudiation of violence. Activists arrested in flagrante were poorly placed to make a plausible claim that their apparently instantaneous conversion to non-violence was just the final stage in a long, private but irreversible dissociation from armed struggle. To buckle immediately under the pressures of arrest implied only a feeble attachment to the ideals by which they had justified their violence and to the comrades whom they had betrayed. Why should their rejection of violence be regarded as any more secure and as a reliable basis for the concession of private rewards in the interests of public safety?

Although a transformation in social and political beliefs is required of participants, the legitimacy of the exchange rests on a presumption of their continuing idealism. The same altruistic motivation which drew activists into armed struggle to reshape the political order rather than for personal gain must carry over as the credible inspiration for collaboration and readiness to accept the risks of revenge by those betrayed. However, acknowledgement that armed struggle might have been fuelled by disinterested and-however aberrantly expressed or interpreted-public-spirited ideals came perilously close to recognising that armed struggle was straightforwardly political, not simply criminal-something that Italian governments have consistently refused to accept. Armed struggle has therefore to be simultaneously political and non-political, the designation shifting according to whether we are describing the world which the pentiti are leaving or the world still inhabited by their unrepentant accomplices. The case of pentimento thus exemplifies what Mauss called the 'polite fiction... and social deceit' surrounding gift-exchange (I990: 3). Since the element of self-interest has to be repressed both by pentiti striving to convince courts that their conversions are sincere and by a state keen to reassure the public that confessions serve to protect it from renewed violence, pentimento provides a clear instance of what Bourdieu, following Mauss, identifies as 'collective miscognition' (Bourdieu I997: 232).

\section{Personalising the prestation}

For the most important pentiti, high status in the world of armed struggle is abandoned in exchange for an initially ambiguous moral 
identity en route to an often precarious reincorporation in ordinary social life (7). Given the slow pace of Italian justice and the several trials in which the pentito may be either a defendant or a key witness, the status transformation of the exchanger between the first instalment of a confession and the completion of the exchange by the final judicial sentence can take several years. The entire period was fraught with risk since pentimento was initially introduced without any formal arrangements to protect the exchanger. Regular witness protection programmes were not established until I99I; until then protection measures were almost entirely at the discretion of individual magistrates (Falcone I 992: 46). If pentiti failed to convince their interlocutors of their credibility, they were likely to be returned to prison where they were at the mercy of those they had tried unsuccessfully to betray. To offer a confession thus meant that a pentito had to put himself in the hands of the representatives of the state without any firm guarantee that his information would be believed, that he would or could be protected against retaliation by those he had betrayed or that courts would ultimately honour the exchange envisaged by law i5/ı980. Falcone's observation about the first mafia pentiti applies equally to their terrorist predecessors: 'I know how hard they found it to talk about themselves, to tell of crimes without knowing what the consequences of confessing might be for them but knowing that on both sides of the barricade were hidden enemies ready to make them pay dearly for their violation of the code of silence... an indifferent State on the one hand, and an organisation enraged by their betrayal on the other' (1 992: 52-3).

To protect themselves, the best-informed pentiti tried as far as possible to personalise their exchanges. The first Red Brigades collaborator, Patrizio Peci, insisted on making his initial confession to General Dalla Chiesa, not only because Dalla Chiesa symbolised the direct 'military' antagonists of the BR but also because he had had responsibility for prison security (Dalla Chiesa I 984: 252; Peci i 980: I9). Likewise, many of the major mafia collaborators-Buscetta, Calderone and Mannoia-singled out Falcone as the privileged, and sometimes exclusive, recipient of their confessions (Falcone I 992: 26-7, 50, 72); others chose Falcone's equally respected colleague, Borsellino. When pentiti decided to reveal what they felt to be unusually important information, they often asked for an appropriately senior magistrate to be present (Caponnetto I 992: 55). Judicial 'partners' were selected by pentiti as the

(7) I shall confine my examples of pentiti to leftwing terrorists. For an analysis of the much smaller world of rightwing violence, in which pentimento played a lesser role, see Ferraresi ( 1996$)$. 
people most likely to provide efficient protection, appreciate the significance of what was being conveyed in the obscure and allusive argot of armed struggle or mafia, and ensure that the most damaging revelations were not suppressed, censored or diverted in their progress towards courtroom verification.

Once the exchange partner had been selected, a sequence of private negotiations began. Pentiti tested what their chosen partners could achieve for them by way of safety and other benefits and assessed the capacity of their interrogators to grasp the nuances in their first revelations. On the other side, police and magistrates wanted immediately verifiable information so as to confirm the pentito's credibility and justify the expense of protection. Peci initially demanded a pardon and a passport in return for his confession: Dalla Chiesa promised to pass on the request with his own support for its consideration, but required in return an indication of weapons' caches as a sign of Peci's good faith and practical value (Peci I 983: I 96). Minor exchanges therefore preceded the transmission of the most important information at the pentito's disposal. Not uncommonly, the relationship progressively established with individual policemen or magistrates encouraged pentiti to reveal details they had planned to conceal: an anti-terrorist police officer noted the tension which arose when a pentito who had established friendly relations with his men unexpectedly decided to reciprocate their goodwill by revealing the identity of the murderers of one of their colleagues (Genova I985: 9I). Such relationships could be long-term. As long as details of the confessions had yet to be tested in court or the responsibilities and motivations for particular crimes remained uncertain or incomplete, a continuing relationship between pentiti and their interlocutors had to be maintained. In some cases, the relationship persisted even after pentiti had been released from prison, their police protectors helping them to find accommodation or employment and to a limited extent even replacing the friendships severed by the decision to collaborate. The head of the Palermo prosecutors' office remarked on the interminable telephone calls he continued to receive daily from the mafia pentito Contorno, then in the US grappling with work and family problems (Caponnetto i 992: 57).

Personalising the exchange did, however, inevitably raise suspicions that alongside the publicly beneficial transmission of the major valuable, a series of less licit transactions to the merely private benefit of participants might be taking place, incorporating a gimwali dimension into what ought to be a pure kula event. Accusations, further incited by the secrecy of the confession process, were often voiced-not only by the 
defence lawyers of those incriminated-that a pentito's credibility or favourable treatment depended on including names that police and magistrates wanted to hear. Allegations were persistently made that magistrates might be using the contents of confessions for their own career advancement or for the benefit of friends or political parties, concealing or censoring information that might be damaging-in effect converting parts of what should be kula, exchanges of exclusively public concern, into kitoum, valuables for purely private advantage (8).

\section{Collective dimensions of confessions}

Exchanges are personalised but bring participants together as representatives of wider collectivities. The value of pentiti themselves depends on their membership and knowledge of an armed organisation, as specified in law I 5/ . 980: the benefits are not available to lone gunmen. To make a confession initiated the kind of event which Mauss characterised as a total prestation. The pentito's own past, present and future selves were donated to the state by repudiating violence and breaking off relations with accomplices, removing the mask of a 'battle-name' and resuming a former identity. For the most informative and exposed pen$t i t i$, this resumption was often temporary: from I99 I onwards, it has been possible to establish a wholly new legal identity, altering the details of name, birth, baptism, residence, education and employment, without the fact of the change or its particulars becoming public (9). Furthermore the terms of the i 980 law required anyone wishing to claim the benefits available to pentiti to identify and incriminate others, setting in motion a potlatch of former comrades and weapons. No one could be spared, since reticence or false testimony risked the loss of credibility and benefits. Moreover, the requirement to demonstrate a complete rupture with their criminal organisations strongly encouraged pentiti to describe their activities and relationships in formal organisational terms so that they could show the sharpest and most definitive break.

(8) On kula and kitoum, see Leach and Leach (1983). Falcone describes the kinds of accusations which were frequently levelled at him (I992: 5I-3); he also acknowledged an unexpected private benefit from his exchanges with collaborators: 'Knowing and working with these mafiosi has profoundly affected my attitudes to people, and even my beliefs... the Mafia have taught me a lesson in morality' (I992: 55).
(9) Changes of name alone were already possible but, as happened in the case of the pentito Roberto Sandalo in 1985 , the details of old and new names had to be published in the Gazzetta Ufficiale accompanied by an open invitation to lodge objections. Law I5/199I and legislative decree I I9/I993 established the procedures for secret changes of identity for pentiti and their families. 
Exchanges of information and interpretations between pentiti, who review their pasts in the language of organisational hierarchies, and magistrates, who work within the penal code's simple categorisation of relative responsibility in criminal organisations, tended to confer an often implausible order on the nature and evolution of clandestine political violence (Iо). Structure and purpose in groups without membership cards and with quite unevenly distributed access to information came to be distilled out of myriad encounters, exchanges, documents and sheer happenstance. Casual encounters became purposeful meetings; fringe sympathisers, committed members; wishful thinking, organisational directives. As confessions fitted the messy reality of armed struggle into the tidy categories of the penal code, many of the volatile, ambiguous and mistrustful relationships were transmuted into a fixed collective portrait of the 'community of armed struggle' ( I I). The resulting authorised version of the nature of political violence was thus partly an artefact of the features of the exchange relationship which produced it.

Once confessions by different pentiti are combined into a single consistent account of an act or organisation of violence, their authors share a fate tied to its plausibility in court. Contradictions between individual stories threaten to sabotage the exchange for everyone: coherence produces maximum benefits. The exchange therefore takes on a further potlatch-like dimension insofar as it combines solidarity among givers and magistrates with an agonistic stance towards the unrepentant: the advantages to be gained by those who confess are directly linked by law I5/1980 to an increase in penalties for fellowconspirators who do not. Like the advantage gained by the Kwakiutl potlatcher who can accumulate resources from lesser clan members, the achievement of the status of pentito-someone who has verifiably renounced violence and provided full and truthful accounts of crimes-depends on the accumulation of further supporting confessions which tally with the candidate-pentito's version.

The decision by Parliament to introduce pentimento naturally committed the members of a different collectivity, the judiciary, to complete the exchange-a restriction on judges' freedom of decision which was sometimes publicly deplored and occasionally flouted in sentences (Moss I989: 225, 301). In fact, neither the investigating magistrates nor the judiciary played a simply passive role. The more experienced investigating magistrates-notably Caselli, Laudi and Vigna-

( го) As defined by articles 270-bis, 284 and 306 of the penal code.
(I I) Arlacchi (I 992: vi) makes a similar point in relation to descriptions by mafia pentiti. 
published commentaries on the detailed interpretation of the single articles of the repentance legislation and created an informal interpretive community to discuss the problems of ensuring its consistent and efficient application (e.g. Laudi I 983; Caselli et al. r 989). Judges and jurors then had to decide how far the conversions of pentiti were genuine and their confessions complete, and the law's widely-set limits of maximum and minimum sentence reductions provided considerable scope to make judgements about the scale of benefits appropriate in individual cases. Further juridical issues on the receipt and value of the confessions which had to be resolved in the courts are discussed below.

The Italian public also had a direct opportunity to express its collective view on the legitimacy of pentimento when law i $5 / 80$ was submitted to referendum in $198 \mathrm{I}$. Whatever its acknowledged value in helping to reduce political violence, the institution aroused much the same kind of moral ambivalence that Mauss ascribed to the nature of giftexchange itself. Both the exchange and the people who made use of it were widely regarded with disquiet, in part because the outcomes of collaboration produced clear inequalities in punishment determined by differences in motivation and readiness to confess rather than the seriousness of the crime, in part because many Italians felt uneasy about the total reversal of loyalties and values demanded by the law. In i 980 President Pertini had publicly criticised pentiti as assassins without ideals and declared that he would never grant a terrorist, repentant or not, a pardon. Then and later, public opinion has also seemed more hostile than sympathetic: although far more Italians regard pentiti as genuinely repentant rather than simply opportunistic, nearly twice as many attribute confessions to cowardice rather than courage (Forcella I 988: 20). Nonetheless, however mixed voters' views on the morality and motivations of the pentiti themselves, the law was endorsed in the I 98 I referendum by a majority of more than four to one. Even when the magnitude of its benefits subsequently became clear-the most valuable leftwing pentiti, Peci and Sandalo, were released after just 3 years and $2^{1 / 2}$ years respectively - no widespread concern that justice had been entirely sacrificed to political expediency surfaced. Even the members of the category likely to be most hostile to pentimento-victims or their kin-were largely muted in their criticisms, reserving their strongest protests for the recurrent proposal that the state make a unilateral gift of an amnesty or general reduction in sentence (indulto) to all terrorists to provide a formal public closure for gli anni di piombo. Occasional attempts to mobilise the associations of victims to campaign for the law's repeal never gathered any public momentum (Scorti i 985: 220): since 
some close kin of the most prominent victims had publicly forgiven their aggressors, they were unlikely to try to undermine the incentives for repentance and remorse.

\section{The evolution of pentimento}

\section{The dynamics of extension}

Since I980 pentimento has evolved in several ways. First, recognition has been given to new categories of participants, provided that they are linked to organised criminal violence. Efforts to extend its application to cover crimes which are essentially individual initiatives and do not involve violence have failed. Second, the range of the terms of exchange has been broadened, mainly in response to the emergence of exchangers who were ready to offer a less than total prestation of their identities and relationships. Third, new kinds of benefit have been made available to participants, allowing for a more rapid reciprocation for collaboration than was envisaged by the original legislation. Fourth, the incentive to participate in pentimento exchanges has been further reinforced by excluding the unrepentant members of organised crime from benefits accruing to prisoners through general amnesties and reductions in sentence (indulti), presidential pardons and the prison reform law of I 986 ( 12 ). Underlining this exclusion has been the repeated and overwhelming rejection by Parliament of all proposals simply to reduce the sentences of convicted terrorists which have been presented since I 989 (most recently, Cento I 998). Finally, the procedures for assessing credibility and obtaining benefits have been diversified, bringing new participants into the circulation and acknowledgement of confessions. Until the mid-I990s the development of pentimento was mostly towards further expansion; thereafter, however, the emphasis has turned towards making the exchange a more precisely calibrated transaction available only to a more carefully screened category of exchangers.

Different factors have been responsible for this evolution. One important impetus was a direct consequence of its initial success, which far exceeded the expectations of its architects and greatly extended the pool of potential participants. The earliest confessions generated several

(I2) Only pentiti were able to take advantage of the amnesties of I98I and I986. Maiello
(I997) analyses the use of amnesties in Italian responses to crime. 
hundred arrests, not only dismantling the armed groups which were still active but uncovering a decade's-worth of details on myriad violent episodes and many long-defunct minor groups. The revelations swept into jail hundreds of activists who differed greatly in their attitudes towards the state, the extent of their direct involvement in violence and the amount of information at their disposal but who were similarly confronted with irrefutable evidence of their participation and therefore with the decision to collaborate or not. The advantages of doing so, and avoiding heavy jail terms for even fringe involvement, were underlined in $198 \mathrm{I}$ by the outcome of the first trials based on pentito evidence which demonstrated that courts were ready to regard its authors as credible and honour their collaboration by large reductions in sentence. Having to cope with the unexpectedly large number and variety of collaborators pushed the government into refining and extending the terms of pentimento exchange. Furthermore, this striking success in accelerating the end of political violence suggested that opportunities to make similar exchanges might be introduced to combat other forms of equally organised but non-political crime. The consideration of such an extension was made more urgent by the rise in mafia violence which followed the breakdown of the fragile alliance between rival factions in the early I 980 s and culminated in the murder of the magistrates Falcone and Borsellino in $\mathrm{r} 992$.

In several ways, the evolution of pentimento follows rather closely Mauss' sketch of the alleged historical shift from total prestation via exchange-by-gift to individual contract ( $1990: 46,70$ ). Mauss identified three key dimensions to this trajectory: a move from total to limited commitment among partners, a 'reduction in periods of time formerly arbitrary' and, implicit in his comparison of potlatch and Melanesian gift-exchange, the incorporation of a wider range of participants in the exchange than merely senior figures exchanging on behalf of, or at least committing, lesser members (Mauss i990: 36). Each of these three elements-greater specification of the contents of exchange with reduced discretion for participants, embedding of time-limits into the exchange, and the admission of minor participants-has marked the main stages in the evolution of pentimento.

\section{Admitting dissociati to exchanges}

The arrests which followed the first confessions diversified the pool of potential collaborators into three categories. The first contained the fully-collaborating pentiti, who, as the arrests continued, found them- 
selves surrounded in jail by the unrepentant and vengeful comrades whom they had betrayed and who demanded that, at the least, they retract their confessions (I 3 ). The second category consisted of people with little valuable information to offer as a sign of their repudiation of violence. Some were activists whose knowledge had been devalued by their predecessors' confessions; others were fringe participants who had little to reveal. The third category comprised those activists who were ready to acknowledge publicly the futility of further violence and to admit their own responsibilities but not to incriminate their associates. By I $8 \mathrm{I}$ this position had been given a name, dissociazione, to underline the refusal of its adherents to participate in the total prestation of pentimento. It thereby made them ineligible for any of the benefits of law I 5/1980, despite the claims by members and sympathisers that the public repudiation of violence uncontaminated by considerations of personal advantage was a more secure route to social peace than the merely instrumental, probably superficial, impact of pentimento. The government was therefore urged to find ways not only to subtract the pentiti from pressures to recant but also to reciprocate appropriately the lesser gift of self-incrimination offered by those who could not, or did not want to, supply more.

After considerable hesitation, the government eventually reciprocated in two stages. In 1982, law 304 accepted as legitimate exchangers all former terrorists who acknowledged their own responsibilities, revealed what they knew of their organisation and tried to prevent further violence. Further reductions in sentences and a wide range of new benefits were offered. The penalties for serious offences could fall to as low as one-third of normal sentences for pentiti, minor involvement could go unpunished, and the possibility of provisional release from custody and a suspended sentence was introduced. To prevent the perverse effect of lighter sentences encouraging a renewal of violence, eligibility was confined to those whose criminal activities had ceased at least four months before the law came into effect and who collaborated within eight months of its introduction (I4). This exchange was quickly taken up. About $70 \%$ of the nearly 400 leftwing terrorists arrested in the wake of the first confessions made full (34\%) or partial $(66 \%)$ confessions: a substantial number were released from prison. Subsequently, for those who did not take advantage of law 304 or had been identified

(I3) At least three terrorists suspected of having collaborated were murdered in jail; another, released after questioning by police, was killed by other members of Prima Linea.
(14) The law was prorogued once, doubling the original time limit of $\mathrm{I} 20$ days ( $\mathrm{dl}$ n.695, I Oct. I 982). 
after its expiry, the government provided a further exchange opportunity in 1987: law 34, similarly time-bound, offered smaller sentence reductions for those who restricted themselves to admitting their own involvement, made a formal declaration of repudiation of violence and provided evidence that all contacts with their former organisations had been broken. 56 I former terrorists applied for these benefits (Caselli et al. I989: 452). About one hundred refused to consider any kind of exchange and were still in jail ten years later serving their full sentences ( I 5).

The characteristic of the exchange relationship between terrorists and their former enemies as a total prestation was significantly weakened by the laws of 1982 and 1987 , which required collaborators to make fewer sacrifices of their own identities and of their comrades. Although altruism was thus recognised, the exchange was increasingly dominated, in practice and theory, by self-interested calculation. For, as Bourdieu ( 1 997: 237-9) and Callon ( I 998: r 2- I9) have pointed out, the embedding of an exchange in specified time constraints shifts its meaning away from the spontaneity of a free gift towards an instrumental transaction. The imposition of deadlines on participation certainly encouraged the individual calculation of self-interest. But the calculative aspect was still more firmly underlined by the introduction of the sequencing of benefits so that the first tangible reciprocation beyond ensuring mere survival-and which could grant pre-trial release from custody, suspension of sentence, and the opportunity to take advantage of the standard rewards for good conduct in jail-could occur long before the final sentence was handed down. Earlier and partial rewards for collaboration altered the position of both partners in the exchange. Pentiti and dissociati were handed an incentive to retain at least some information for later use in bargaining for further privileges, and their interlocutors-magistrates obliged to recommend or oppose the concession of new benefits-acquired greater powers to influence or coerce collaborators. Early release from prison certainly made collaborators less vulnerable to pressures from former associates to retract their statements or conceal evidence or return to armed struggle; but it also gave magistrates less time to assess how far individual acts of dissociation from violence were likely to be definitive (I6). What had begun as a total prestation was

(i5) In 1998, 224 terrorists (i 9 I leftwing and 33 rightwing) were still in prison. 147 had been in jail for more than ten years: roughly 5,000 were reckoned to have been through the prison system since I970. I90 had evaded arrest and were mostly living in France. Some of these exiles made unsuccessful attempts to claim the status and benefits of dissociati.

(i6) In the face of the increasing numbers of full and partial collaborators and the declining opportunities to verify the sincerity of their repudiations of violence, the 
thereby transformed into a form of balanced reciprocity in which limited bits of information could be bargained for immediate benefits, allowing scrutiny of the giver to take second place to the evaluation of the gift ( I 7). This shift becomes even more marked in the handling of the extension of pentimento to cover former mafiosi.

\section{Can mafiosi be pentiti?}

The possibility of extending pentimento to encourage the defection of mafiosi was raised in the early i 980 s as soon as the rapid escalation of mafia violence began. But it became an urgent issue in 1984 when, quite unexpectedly, Tommaso Buscetta began to collaborate with the investigating magistrate Giovanni Falcone. Buscetta was not the first mafioso to collaborate, but he was the first boss to do so and to find a magistrate who already knew enough about the mafia to treat insider revelations seriously and make them the basis for a successful large-scale prosecution. Buscetta's example and active encouragement prompted a handful of other mafiosi to collaborate, confirm his own testimony and shed light from various quarters on how and why relations within the mafia had degenerated into full-scale factional war.

Since confessions by mafiosi were not covered by law i 5/1980-the only repentance law still in force after the expiry of laws 304/1982 and 34/1 987 - they had to be treated as unsolicited gifts, with no clear framework for the protection of the giver or state reciprocation. Between I 984, when Buscetta's information was converted into nearly 400 arrest warrants, and I99I, when the state finally acknowledged the value of admitting mafiosi to pentimento exchanges and fixed their terms, mafia pentiti and their materials had to be handled in an ad hoc fashion by individual police and magistrates. The prolonged period of uncertainty about how to respond to these unsolicited gifts of valuable information reflected in part some basic differences between terrorist and mafia pentimento, in part the contrast between the conventional wisdom on mafia and the accounts of pentiti.

In the first place, the motivations for the confessions of mafiosi appeared quite different from those of their terrorist predecessors. Failure of their political project was a driving force for terrorist pentiti, so collaboration signalled their recognition of the superior power and, in

Ministry of Justice turned the process of evaluation of candidate-dissociati over to already established dissociati for a period (Morucci I997).
(17) Law 304/1982 also attempted to protect the value of the information by introducing sanctions, entailing the forfeiture of all benefits, against false or reticent confessions. 
several cases, authority of their antagonist (Peci I983: I94; Genova I 985: 58). Mafia collaborators like Buscetta, however, emerged from the losing side in an internal mafia struggle with no personal benefits to demand or obtain except protection for themselves and their families (Arlacchi I994: 252). It was therefore easy to ascribe their dominant motivations to revenge and to suspect that their revelations were carefully calibrated to incriminate their enemies and protect their friends (I 8). Confidence in the reliability of evidence inspired simply by revenge was not likely to be high. Indeed, the wisdom of accepting unsolicited testimony from participants in organised crime had been seriously undermined in the furore which followed the arrest and prosecution of a popular television personality, Enzo Tortora, for drug trafficking on the unsupported word of a fringe camorra member (I9). Unlike terrorists, whose professedly public-spirited motives for collaboration could be seen as consistent with the absence of any personal benefit from the violence they had engaged in, mafiosi had been led into crime by their self-interest and, it was argued, that same self-interest would determine how much help they would give the state to reduce violence.

Moreover, the extent to which collaboration entailed genuine repudiation of the activities and ideals of Cosa Nostra-and therefore produce lasting public benefits which could justify reductions in sentence-was quite unclear. Buscetta himself refused to accept the label pentito, stating that he was seeking no favours from the state and refusing to disavow his past (Arlacchi I994: 3). He did not reject the mafia as such, only the perversion of its ideals by his enemies from the victorious faction, and he did not acknowledge the authority of the state: 'I'm collaborating with you because I respect you', he told Falcone's judicial superior, 'but you represent something hostile to me, an enemy' (Caponnetto i 992: 56). Moreover, while many of the tiny ramshackle organisations of armed struggle had already dissolved by the time their activists had confessed and any chance to rejoin them had therefore disappeared, mafia groups were still very much in existence: some might easily reabsorb those collaborators whose confessions had turned out to their advantage by incriminating rivals.

For such reasons, the doubts about the value of the gifts offered by mafia collaborators were hard to dispel. Practical considerations also

(i 8) One pentito (Contorno) was arrested on a return visit to Sicily to take private revenge on enemies he had already testified against in court.
(19) Tortora was arrested in I $_{9} 8_{3}$, convicted in $1_{9} 85$ but had his conviction overturned on appeal in 1986. For details of the case, see Foschini and Montone ( I 997). 
intervened. Mafia pentiti had often grown up in mafia families and therefore had vastly more potentially relevant information at their disposal than the members of most short-lived or locally-concentrated terrorist groups. Problems of memory and involuntary selectiveness were therefore far more likely among mafiosi than among terrorists. Furthermore, since a cardinal rule, however regularly flouted in practice, among mafiosi was to tell the truth (Falcone r 992: 42), mafiosi could easily offer erroneous information, originally learned from others, in good faith. Some types of reticence were explicit. Buscetta refused to talk about the links between mafia and politics, claiming that, since the people to be named would deny them, had power to prevent their investigation and would take revenge on him and any magistrate who attempted to follow them up, to provide this kind of information which could not in any case easily be verified by independent evidence would weaken the force of the entire confession (20). The information in the hands of senior mafiosi was much more damaging to powerful interests than anything that terrorists could confess; but precisely the refusal to reveal it encouraged suspicions that the entire collaboration was designed to advance private, not public, interests. If mafia confessions were intrinsically so selfinterested, unreliable or incomplete, their value was far too uncertain to permit their conversion into exchange items.

Many of the doubts were, however, dissipated by the success of the prosecutions based on Buscetta's portrayal of mafia relationships and responsibilities. In I 99 I, therefore, pentimento exchanges were expanded to admit mafia collaborators. The rules were rewritten in ways which divided up the responsibilities for receiving the gift of a confession and formalised the relationship between giver and recipients. Mafia pentiti became eligible for the same sentence reductions which had been available to their terrorist predecessors. They also qualified, along with a wide array of participants in other kinds of organised crime, for a newly-established system of police protection which included detention outside prison, a regular stipend and the option, in extreme circumstances, of a legal change of identity (2 I). Concession of these benefits was, however, transferred from the discretionary powers of individual magistrates to a committee in the Ministry of the Interior, so that

(20) Buscetta said that if he had told all he knew about the relations between mafiosi and Andreotti, he and Falcone would both have found themselves committed to a mental asylum (Arlacchi i 994: 9; $c f$. Falcone 1 992: 26, 47).

(2I) The full list of offences for which collaboration is rewarded (mainly those associated with organised violent crime such as mafia and terrorist group membership, drug-trafficking and gun-running, carrying a minimum 5 -year prison term) is contained in art. 380 of the code of penal procedure. 
exchanges between items in a confession and forms of protection could no longer be negotiated solely between pentito and magistrate. The reduction in the personalisation of the exchange was reinforced by two further features. First, candidate-collaborators were required to sign a formal contract, itemising their legal, financial and family positions and containing an explicit agreement to abide by the terms of a speciallytailored protection programme (22). New levels of verifiable detail about their individual circumstances therefore had to be provided along with the confession itself. Second, to ensure the value of the information contained in the confessions, penalties for false, libellous and reticent declarations were introduced (23). In effect, recognition as a valuable mafia pentito came to depend on the scrutiny of a greater depth of information by an expanded range of recipients, allaying some of the concerns about the reliability of confessions by ensuring a more intensive scrutiny of their authors. What the r99 I measures achieved was to expand the participants and content involved in pentimento exchanges: a wider set of givers, a broader range of information, and a more differentiated array of recipients.

The incentives offered by such measures only became effective once courts had shown themselves ready to acknowledge the value of pentiti testimony-hardly a foregone conclusion, given the notorious power of the mafia to restrict the supply, and influence the judicial treatment, of hostile evidence. In this case, however, Buscetta's account of mafia structure was definitively endorsed by the Court of Cassation in early I 992, the verdict signalling that the judicial system was no longer vulnerable to traditional mafia pressures but so little taken for granted that it prompted a champagne celebration by the prosecutors (Stille i 996: 349-50) (24). As in the earlier case of terrorism, the demonstration that the gift of confession would be reciprocated encouraged wider participation. In I 990 some 35 pentiti had passed through the Palermo courts plus a few more in neighbouring jurisdictions (Falcone r 992: 46). By I 997, however, some 424 mafiosi were collaborating, roughly $7 \%$ of the estimated 5,700 mafia members, alongside a further 807 pentiti from

(22) The regulation of a pentito's rights and duties by a formal contract had first been proposed by anti-mafia magistrates (Caponnetto I992: I I9).

(23) Art. 8, law 203/r99 I. Similar sanctions had been included in the 1982 and 1987 laws but were not part of the only pentimento law still in force ( $15 /$ / 980 ).

(24) The definitive confirmation of the value of Buscetta's gift is believed to have been the direct cause of the mafia murder of Andreotti's Sicilian proconsul, the Euro MP Salvo Lima, because of his failure to bring sufficient pressure on the Court to annul the convictions. The demonstration that trials based on confessions could be proof against challenge probably helped to seal the fate of the prosecutors Falcone and Borsellino, both murdered within a few months of the Cassation verdict. 
mafia-like groups elsewhere in Italy (Violante i 997: I 59, Tab. 5). A different protection programme had to be established for each recognised pentito, since their circumstances could vary markedly: in 1997 only $2 \mathrm{I} \%$ of the more than one thousand collaborators were still in jail, $5 \%$ were under house arrest, and $74 \%$ were free in Italy or abroad (ibid.). The costs of protecting such a widely dispersed group, of course, grew rapidly. The protection budget, established in I99 I at Io milliard lire, had risen to $5_{5}$ milliard lire by 1997 (Manganelli I 997). Not only were the costs and the complexity of organisation becoming prohibitive; it was also increasingly difficult for the under-resourced police and magistrature to verify the motivations, accuracy and consistency of the multiplying numbers of confessions. A dilemma therefore appeared. On one hand, success in eliciting confessions prompted calls to expand access still further in order to eliminate organised crime of all kinds; on the other, the increasing costs and the difficulties in checking that a genuine gift was indeed being offered favoured the opposite strategy of restricting and refining the terms of exchange.

\section{Extending eligibility: new categories of pentiti?}

The original model of pentimento for both terrorists and mafiosi made eligibility as an exchange partner conditional on full repudiation of the ideas, practices and organisations of violence, and offered rewards only in return for truthful and complete confessions of demonstrable value to police and prosecutors. A recurrent suggestion has been to copy the extension of exchange to terrorist dissociati and to admit to lesser benefits mafiosi who can show they have cut all ties with mafia and who confess their own crimes but will not incriminate fellow-members. The first of several such proposals was presented to Parliament in I996, its supporters repeating the earlier claim that only by reducing the selfinterested elements in rewards could the authenticity and permanence of the repudiation of violence be assured. Opponents, however, argued that since omertà was one of the principal characteristics of mafia (indeed it was included in the legal definition of a mafia association), any refusal to incriminate fellow mafiosi simply indicated a continuing attachment to a core feature of mafia behaviour; such limited admissions failed to guarantee individual renunciation of violence or sufficient damage to the organisation and therefore fell below the minimum value required for an exchange. Anti-mafia magistrates agreed; and no extension in this direction has been made so far. 
Could pentimento be extended to admit exchangers involved in nonviolent crime-to cover those who had conspired to break the law but had not used physical violence and were ready to collaborate? A controversial and repeated suggestion has been to combat the extensive politico-administrative corruption revealed in the Tangentopoli scandal by allowing reduced sentences, even immunity from prosecution, for any party to a corrupt exchange who, prior to discovery, confesses and names the participants. The government has consistently argued, however, that pentimento exchanges can only be justified by the necessity to undermine an otherwise impenetrable criminal organisation from within; and, unlike terrorism and mafia, corruption has been neither sufficiently organised nor wholly resistant to normal preventive or punitive measures. Related proposals have also been put forward, usually entailing leniency for the discredited members of the political elite and arousing the immediate opposition of magistrates and the public (25). Only one extension of the principle of pentimento has in fact been accepted: the concession of a residence permit to an illegal immigrant forced into prostitution who collaborated with police to incriminate the leaders of the organisation for which she works (law 40/ı 998, art. I6). The novelty of this type of exchange is that the behaviour to be forsworn is the product rather than the source of violence and the benefit obtainable is not a reduction in sentence. Whether it will be a precedent for the invention of further variants with new categories of participant and new types of reward remains to be seen.

Recent proposals to alter the terms of pentimento exchange, however, have been restrictive rather than expansive. In I997, to cope with the costs of the increasing number of mafia pentiti and the difficulty of assessing the value of their confessions, the government proposed to set narrower limits to both admission to, and benefits of, pentimento (26). Protection programmes were to be restricted to former terrorists and ex-mafiosi who-no matter how important their confessions-would have to serve at least one-quarter of their prison sentence before release into an alternative form of detention. State control over the timing of exchanges, which had threatened to pass to pentiti who bargained every further piece of information for some direct benefit and enjoyed a stipend while doing so, would be recovered in two ways. First, all pentiti would be compelled to sign a declaration, within six months of initiating

(25) In I 993 a government proposal to offer suspended sentences to defendants who confessed their corruption had to be withdrawn after an immediate public uproar and threats of resignation by the 'Clean Hands' magistrates in Milan.

(26) Ddl 2207 ( I 997), still under consideration by Parliament three years later. 
their collaboration, identifying the full set of issues on which they intended to collaborate and stating that there were no other matters on which they had relevant information. Second, all protection programmes, and the conduct of their beneficiaries would be reviewed annually and would not normally last more than five years. In this way the state would retrieve the initiative in exchanges and prevent pentimento from becoming the basis of a long-term publicly funded status, thus restoring its original function as a mechanism for returning transformed to society those who had breached the taboo on violence.

\section{Completing the exchange}

\section{Preserving the hau of confessions}

The legislation of I982, I 987 and i 99 I provided for the withdrawal of all benefits to pentiti if their confessions proved to be untruthful or reticent. However, although some of the practical importance of revelations can be realised at once by the disclosure of terrorist hiding-places and weapons and by the self-incriminating declarations of arrested group members that they are 'political prisoners', the value which confessions appear to possess at the outset is exposed to the risk of serious degradation in the often lengthy period between the initial act of collaboration in a police-station or prison and the final completion of the exchange in court. Their contents can be disavowed by their authors and disputed by those they incriminate; their role in the case for the prosecution can be compromised by changes in the rules of admissible evidence; and their capacity to ensure convictions can be diminished by jurisprudential decisions on what counts as decisive proof. Substantial risks of alterations in value-and the diversion of some of their contents from public to private benefit-exist if the path followed by a confession, the integrity of its contents and the link with its author are not very carefully secured.

When pentimento was introduced, the contents of confessions were formally protected by the standard rules of judicial confidentiality (segreto istruttorio). Documents containing confessions were available only to the magistrates responsible for the investigations, extended in I 978 to include magistrates working on related cases and to the Minister of the Interior. However, these rules had long been flouted in every kind of judicial investigation, and cases of political violence were no excep- 
tion. The dangers which uncontrolled circulation could bring were immediately illustrated in the case of Peci's first confessions: their (partly censored) publication in a newspaper led to the imprisonment of the journalist and his security service source, and the suspicion that their contents had also been leaked by the Minister of the Interior to a senior party colleague whose son had been named and might be helped to avoid arrest led to a narrowly defeated attempt to impeach the former minister, by then the prime minister Cossiga (Stajano I 982: I 95-263). No clearer demonstration could be given for the need to minimise the chance that confessions might follow deviant paths (27). In such cases, easily facilitated by the photocopier, the pentiti themselves had no responsibility for the escape of classified information. Knowing that such circulation is possible, they have exercised the power not to include details which they think cannot be protected by magistrates and which, if made public prematurely, have the capacity to provoke attempts to destroy the value of the confession as a whole. Buscetta's refusal to discuss the relations between mafiosi and senior politicians until he judged that the chance of political intervention to nullify his entire testimony had disappeared is a case in point (Caponnetto r 992: 56). Doing what they could to control the keda followed by their confessions was therefore vital for pentiti with revelations incriminating the powerful. But it is also important for investigators who want to ensure that the full potential value of a confession is realised.

The pentiti's retention of the information which their giftconfessions contain is also the basis for the possibility of compromising, wittingly or unwittingly, their fullest possible value. It enables them to put into circulation potentially rival versions of their original gifts. Two paths may be involved. The first is created by the private exchanges that many of the more prominent terrorists engaged in with their victims or their victims' kin, so that the public sequence of pentimento exchanges has often proceeded alongside a parallel set of private exchanges. Although pentiti have to make their first moves in a legal context, many have later tried to achieve some form of private reconciliation with the people they have damaged. Frequently the fact, and less frequently the detailed content, of such meetings has become public, which has led the families of some victims to resent the pressure to reinforce the legitimacy of the state's exchange by publicly declaring

(27) In 1984 a tip-off that a weekly magazine was about to publish Buscetta's confessions forced Falcone and his colleagues to work continuously for three days to get nearly four hundred arrest warrants executed before the confession became public (Caponnetto I 992: $54)$. 
their own forgiveness of, and reconciliation with, a pentito (28). Here, however, the important aspect is that details may be provided in these personalised accounts which were not incorporated into the official version contained in the confession and may be in contrast with it, causing doubt to be raised about the veracity of either version. Some pentiti have certainly felt they owed their victims a more exhaustive and motivated account of the tragedy than the one they have provided for courtroom consumption (e.g. Lenci i 988: I 5 I).

A second path-which is potentially much more threatening to the value of a confession-is established by the invitation to its author to present a differently tailored, and therefore possibly inconsistent, account of its major features in newspaper or television interviews or in commercially published books. At least eight former terrorists have written or collaborated on accounts of their lives of violence, as have the two major mafia pentiti of the I980s, Buscetta and Calderone. These accounts can be sources of direct financial value to the authors: Buscetta's main income for three years came from the royalties he earned by collaborating on his life-story with the journalist Enzo Biagi (Arlacchi I 994: 260). But the circulation of potentially competing versions of the real valuable may pose a threat to the integrity of the original. Such versions are provided free of any sanctions against falsity and reticence and can carry no guarantee of accuracy. There is therefore room for substantial variation in detail or in overall emphasis, not least because the public version is specifically designed for commercial circulation and the collaborating hand of a journalist or academic replaces that of a magistrate or police-officer (e.g. Peci I 983; Arlacchi I 992; Curcio I 993). Given the slow pace of the Italian judicial system and its two-tiered appeal process, the interviews and books on which pentiti have collaborated have often appeared before the definitive verdict on the value of the original confession has been reached. So sharp-eyed defence lawyers have occasionally been able to exploit apparent inconsistencies between legal and commercial versions on points of detail (29). At a more general level, too, clear variations in emphasis can undermine the claim that the original confession is the simple unvarnished truth. Falcone certainly said of his best-known pentito: 'With [Buscetta] we began to look inside [the mafia] ... above all, he gave us a broad, far-reaching global vision of the organisation. He gave us the essential keys to the interpretation of the

(28) In one case the full set of letters between aggressor and victim has been published (Lenci I 988 ).

(29) Thus details in the account published by Leonardo Marino (I992), the principal accuser of Sofri, Pietrostefani and Bompressi as responsible for Calabresi's murder, were cited by Sofri's lawyer in his second appeal to the Court of Cassation to demonstrate the pentito's unreliability on key points. 
Mafia, a language, a code' ( 1992: 23). But Arlacchi notes how greatly the account given to magistrates by the mafia pentito Antonino Calderone, which stressed the accepted organisational hierarchy, division of labour and obedience to tacit rules, differed from the account which Calderone provided to Arlacchi himself, which was full of the coincidences, breaches of convention, betrayals and few-holds-barred struggles of actual mafia behaviour (Arlacchi I 992: v, vi). Emphasis on the casual and coincidental rather than the logic of organisational hierarchy tends of course to undermine the broad perspective adopted in the legal version and can thus cast doubt on its reliability as a guide to the specific responsibilities of individual defendants. So once the number of mafia pentiti grew rapidly in the early i 990 , the threat posed by the circulation of an increasing volume of potentially rival commercially-inspired treatments of the matters dealt with in confessions was felt to be sufficiently serious to require intervention. In I992, therefore, entry into a protection programme was made conditional on signing an agreement to talk to no one except police and magistrates on any matter covered by the confession itself (law 356/1992, art. I3). Exceptions could be made for bona fide scholars (e.g. Arlacchi I 992; I 994), but for most purposes the pathways which had been used for the imitation valuables carrying no certification of their accuracy were closed off.

\section{The obligation to receive and reciprocate}

The final phase of the gift exchange is completed in court and, because of the practice of putting up to several hundred defendants on trial together, is likely to take place several years after the exchange was initiated. Before reciprocation is made, however, several issues have to be resolved. First, are the courts either obliged or entitled to receive confessions from which the authors have dissociated themselves by retraction or by refusal to appear in court to provide confirmation, either as a co-defendant or a witness? Put in other terms, how far can a confession preserve its force-its hau-once it has been disconnected from its giver? Second, once the court receives a confession, should its potential value in the prosecution's case be set low (merely circumstantial evidence) or high (proof sufficient to convict)? Third, is the value of the confession indivisible or fractionable? Can some parts be regarded as worthless without destroying the value of the rest? Should the fact that some elements can be confirmed by independent evidence automatically confer equivalent value on the parts that rest solely on the pentito's 
unsupported word? Again, are the parts based on information gathered at second-hand (de relato) to be treated as possessing equal value to those based on the pentito's direct observation or experience? In their various ways, these questions amount to contemporary versions of issues that Mauss himself addressed on the nature of the continuing tie not only between givers and their gifts in Maori and Melanesian exchanges but also between writers and their texts in early 2oth century French copyright law (Mauss I 990: 67).

Most of these questions appeared only infrequently during the completion of the exchanges with terrorist pentiti in the r980s. The legislation of I980-I 987 made it clear that pentiti had to appear in court to confirm the detail of their confessions and respond to challenges. They had in any case a real incentive to dramatise the transformation of their identity as publicly as possible in order to ensure the fullest benefits; and most did so, helped by the readiness of many judges to allow them considerable latitude in describing their careers into, inside and out of violence. Inciting those they had betrayed to insult them in open court as 'infami' (traitors) was itself useful evidence of the rupture with their pasts (30). In practice the confessions encountered few serious challenges. In most trials the large majority of defendants had already confessed at least their own responsibilities; those who remained unrepentant (irriducibile) refused to play any part in the proceedings because they did not accept the legitimacy of the court to judge them: 'the revolution can't be put on trial' ( $3 \mathrm{I})$. In the rare cases where pentiti could not or would not appear to confirm their confessions, courts were ready to admit them as evidence anyway (32).

In the I99os, however, conflicts over the value to attribute to confessions became much more common. In the first place, the change from an inquisitorial to an adversarial code of penal procedure, introduced in 1989 , shifted the probative emphasis from the written documents gathered by the prosecution in the pre-trial investigations to the oral exchanges in court where prosecution and defence met on more equal terms. A direct consequence was to make it harder for prosecutors to provide unequivocal courtroom proof of a looselydefined offence like 'membership of the mafia' (Falcone r992: I43):

(30) Their lawyers would often ask for a formal record to be made of the insults directed at them.

(3I) The only significant challenges to confessions occurred in the trial for the murder of the journalist Walter Tobagi, when the pentito Marco Barbone was repeatedly accused of reticence (Scorti i 985 ).
(32) The most significant example was Carlo Fioroni whose confessions were a key but very controversial part of the prosecution case against the so-called 'April 7' defendants; after release from jail, Fioroni had gone abroad and refused to return to testify in 1984 . The court accepted his original testimony. 
under these circumstances, a confession incriminating the defendants was the most direct evidence, provided it could be tested successfully in the presence of its author. A second source of conflict lay in the classical mafia approach to trials as opportunities publicly to frustrate the prosecution, often by intimidating or suborning witnesses: the power and skill demonstrated by successfully facing down charges, especially those charges widely believed to be entirely justified, was a well-established route to higher status in the mafia. Now the stakes were raised, and the balance of power tilted away from mafiosi, by the insider testimony of the first pentiti which courts proved ready to accept. Attempts to intimidate witnesses and discourage pentimento were naturally redoubled. Multiplied, too, were the legal challenges to the value of confessions as evidence, requiring repeated interventions by the Court of Cassation, Parliament and the Constitutional Court.

Could the court receive confessions which their authors refused to confirm in person? The effort to persuade pentiti and witnesses to retract or refuse to appear, largely by murdering their families and kin, gave this question vital importance (33). Throughout the I 980 s courts had routinely admitted all confessions, a position endorsed by the Court of Cassation. Indeed, the intimidation of pentiti and the murders of the magistrates with whom they had collaborated prompted Parliament, in immediate response to the murder of Falcone in I992, to extend the admissibility to confessions (and other material) gathered even without notifying the people they incriminated or their lawyers. Since the confession remained valid even in the absence of its author to confirm it in court, it preserved the fullest possible quantum of the author's personality at the time when it had been given. Not surprisingly the reversion to attributing overriding value to pre-trial written documents attracted severe criticism since it ran counter to the inspiration of the new code of penal procedure (Neppi Modona I992: ro). Subsequent success in encouraging pentimento and arresting mafia bosses prompted Parliament to revisit the issue in 1997 and to determine that only those confessions which could be directly confirmed in court would be admitted as evidence. However, that decision was itself reversed in 1998 by the Constitutional Court which restored the admissibility of testimony not confirmed in person (34). Once offered, therefore, the gift of

(33) 35 of Contorno's relatives were murdered (Falcone 1992: 46), and some 50 of Buscetta's (Caponnetto I992: 53). To avoid this fate, some wives and family members made a point of disowning their repentant spouse or kinsman as publicly and emphatically as possible (Falcone i 992: 73).

(34) Sentence 36r, October 26 I998. The defence could have its challenges to the testimony recorded. In 1998 Parliament intro- 
repentance retains its original value, even though its giver is not there to confirm it or has tried to annul it. Its force for prosecution purposes remains intact, whatever the subsequent attitude of the author towards it.

As far as the capacity of a confession to justify a conviction rather than simply support other evidence is concerned, the most recent valuations have been mainly downwards. In the I980s, breaking with the tradition that confessions incriminating others were regarded as little more than circumstantial evidence, courts tended to accept a plausible confession as sufficient proof in its own right, even without substantial confirmatory evidence (Magri i993: 636). Thereafter, the Court of Cassation has insisted that confessions must be evaluated both for internal consistency and for independent confirmation. It has also accepted, more controversially, that independent confirmation may consist of other confessions, provided there is no suspicion that they were jointly concocted by their authors. The Court has also discriminated more carefully between the relative value of different parts of a confession. Confessions do not have to be accepted in their entirety: the parts that can be supported by independent evidence are acceptable as proof, those without that support are not. Furthermore, provided additional evidence is available, the parts of a confession based on secondhand information alone can in principle be treated as of equal value to the parts based on direct knowledge or observation. In this way, therefore, the value of a confession has come to be treated as less directly reliant simply on the credibility of its author. Gift and giver may part company over the prolonged course of the exchange without the compromising the integrity of the original gift. Likewise, the value of that gift has increasingly been treated as partible, so that the worthlessness of some parts does not invalidate the whole.

\section{Conclusion}

Pentimento was introduced to defend Italian political and social order from violence-exactly the function that Mauss had ascribed to gifts in earlier societies. But, contra the often edulcorated versions of his views, Mauss was also well aware that the sequence of giving, receiving and reciprocating gifts was itself full of risks and might easily collapse into 
dispute and violence (e.g. I990: 82; $c f$. Karsenti ı997: 357-67). What helps to prevent disaster is the deliberate maintenance of social pretence and polite fiction, the theme with which Mauss begins his essay and to which he returns throughout. Indeed he chooses to conclude his essay with the story of King Arthur's Round Table, which was designed precisely to mask the differences of status, power and prowess among the king and his knights.

Treating pentimento as a form of gift-exchange, and tracking the evolution of its terms and consequences over almost twenty years, illustrates the continuing power of Mauss' analysis to illuminate the issue of containing violence that had originally inspired his study of the gift. Since r 980 pentimento has come to play a steadily more important role in the defence of Italian social life, extending the opportunity for confession and reward to more participants in a wider range of violent activities. At the same time, the forms of the exchange have moved away from total prestations by leading terrorists and mafiosi towards a series of more narrowly defined and explicitly sanctioned gifts and reciprocities involving larger numbers of lesser participants. Throughout this shift, however, the basic features of the original model of pentimento have been preserved: it remains an exchange available only to participants in crimes of collective violence; the very eligibility to participate is simultaneously exposure to heavier penalties and exclusion from any unreciprocated gifts of amnesties by the state; and the gift of a confession acknowledges publicly the superiority of its recipients' models of political conflict and social order.

Mauss remarked that total prestations constitute 'l'instant fugitif où la société prend, où les hommes prennent, conscience sentimentale d'eux-mêmes et de leur situation vis-à-vis d'autrui' (I 973: 275). Pentimento has certainly been one such instrument, a means of shedding light not only on the dark side of contemporary Italian society but also on how close that side lies to the dominant institutions. Far beyond Italy, too, the technology of reconciliation-confessions, apologies and remorse- has become a significant dimension of public debate in relation to the many different cases of past injustices towards indigenous minorities, legacies of the Holocaust, and lustrations in post-communist states (Schwan 1998). Although anthropologists have begun to pay greater attention to collective violence, they have not yet been concerned with the patterns of remorse and desire for expiation which that violence can bring in its wake for participants (35). Renewing Hertz's interest in

(35) Recent anthropological approaches to violence include Malkki (I995), James (I 997) and Apter (1997). 
expiation from a Maussian perspective on confession offers one direction for an anthropology of atonement. It also encourages us to develop Mauss' insights by extending our range of interest beyond the exchange of those commodities that we happen to call 'gifts' today.

\section{BIBLIOGRAPHY}

Allen, N. and James, W. (eds), I 998, Marcel Mauss: A Centenary Tribute (Oxford: Berg).

Andreoli, M., I993, Andavamo in Piazza Duomo (Milan: Sperling \& Kupfer).

Apter, D. (ed.), 1997, The Legitimization of Violence (Basingstoke: Macmillan).

ArlacCHI, P., I992, Gli uomini del disonore. La mafia siciliana nella vita del grande pentito Antonino Calderone (Milan: Arnaldo Mondadori).

-, 1994, Addio Cosa Nostra. La vita di

Tommaso Buscetta (Milan: Rizzoli).

Barbrook, R., I 999, The Hi-Tech Gift

Economy, Cybersociology, 5 .

Biacchessi, D., I 998, Il caso Sofri (Rome: Editori Riuniti).

Bourdieu, P., I997, Marginalia-Some Additional Notes on the Gift, in Alan D. Schrift (ed.), The Logic of the Gift. Towards an Ethic of Generosity (New York: Routledge), 23I-24I.

CaIllé, A., I 996, Ni holisme ni individualisme méthodologique. Marcel Mauss et le paradigme du don, Revue européenne des sciences sociales, XXXIV, I05, I 8I-224.

Callon, M., I 998, Introduction: the embeddedness of economic markets in economics, in M. Callon (ed.), The Laws of the Markets (Oxford: Blackwell), I-57.

Caponnetto, A., I992, I miei giorni a Palermo (Milan: Garzanti).

Caselli, G.C., Laudi, M., Miletto, P. and Perduca, A., I989, La dissociazione dal terrorismo (Milan: Giuffré).

Cento, P.P., I 998, Concessione di amnistia per i reati commessi per finalità di terrorismo, Progetto di legge n.4701, Camera dei Deputati, 20 marzo.

Curcio, R., I993, A viso aperto (Milan: A. Mondadori).

Dalla Chiesa, C.A., i984, 'Testimony' (July I 2 I980), Commissione parlamentare d'inchiesta sulla strage di Via Fani, sul sequestro e l'assassinio di Aldo Moro e sul terrorismo in Italia, Doc.XXIII, n.5, vol.4 (Roma: Tipografia del Senato), 243-366.

Davis, J., I992, Exchange (Buckingham: Open University Press).

Douglas, M. (ed.), I970, Witchcraft Confessions and Accusations. ASA Monographs 9 (London: Tavistock).

Falcone, G., Padovani, M., i 992, Men of Honour, trans. Edward Farrelly (London: Fourth Estate).

Ferraresi, F., I996, Threats to Democracy: the Radical Right in Italy after the War (Princeton: Princeton University Press).

Firth, R., I967, Themes in Economic Anthropology: A General Comment, in R. FirTh (ed.), Themes in Economic Anthropology. ASA Monographs 6 (London: Tavistock), I-28.

Forcella, E., I988, La memoria di piombo, Epoca, 3 I January, i 8-2 I.

Foschini, M.V. and Montone, S., i 997, Il processo Tortora, in L.Violante (ed.), La criminalità: Storia d'Italia: Annali 12 ('Turin: Einaudi), 683-7 I 3 .

Gambetta, D., I993, The Sicilian Mafia (Cambridge: Harvard University Press).

Genova, S., I985, Missione antiterrorismo (Milan: Sugarco).

GetTy, J.A., I 999, Samokritika rituals in the Stalinist Central Committee, 1933-38, The Russian Review, 58, I: 49-70.

Godelier, M., I999, The Enigma of the Gift (Cambridge: Polity).

Gofman, A., I 998, A vague but suggestive concept: the 'total social fact', in Allen, N. and James, W. (eds), I998, Marcel Mauss: A Centenary Tribute (Oxford: Berg), 63-70.

Greer, S., I995, Supergrasses. A Study in Anti-Terrorist Law Enforcement in Northern Ireland (Oxford: Clarendon Press).

Hepworth, M. and Turner, B., I982, Confession: Studies in Deviance and Religion (London: Routledge and Kegan Paul). 


\section{THE GIFT OF REPENTANCE}

Hertz, R., I 996 [1 922], Sin and expiation in primitive societies (Oxford: British Centre for Durkheimian Studies), Occasional Paper No.2.

Hine, D., I993, Governing Italy. The Politics of Bargained Pluralism (Oxford: Clarendon Press).

James, W., I997, The names of fear: memory, history, and the ethnography of feering among Uduk refugees, Fournal of the Royal Anthropological Institute, 3: I I 5- I 3 I.

Jamin, J. and Lupu, F., I987, Le péché et l'expiation dans les sociétés inférieures : mise au point des recherches inédites de Robert Hertz. Cours de Marcel Mauss, Gradhiva, 5(2): 43-52.

Jamous, R., I 999, Élémentaire, complexe: de certains formes d'explication en anthropologie, Archives européennes de sociologie, XL, 2: 279-303.

Karsenti, B., I994, Marcel Mauss : le fait social total (Paris: Presses universitaires de France).

-, I997, L'homme total. Sociologie, anthropologie et philosophie chez Marcel Mauss (Paris: Presses universitaires de France).

Laudi, M., I983, I casi della non-punibilità dei terroristi 'pentiti' (Milan: Giuffré).

Leach, J., and Leach, E. (eds), I983, The Kula. New Perspectives on Massim Exchange (Cambridge: Cambridge University Press).

Lenci, S., I988, Colpo alla nuca (Rome: Editori Riuniti).

Lupo, S., I996, Andreotti, la mafia, la storia d'Italia (Rome: Donzelli).

Magri, P., I993, Le dichiarazioni dei 'pentiti' e la lotta alla criminalità, Aggiornamenti sociali, nn.9-I - 625-40.

Maiello, V., I 997, La politica delle amnistie, in L.Violante (ed.), La criminalità: Storia d'Italia: Annali 12 (Turin: Einaudi), 935-979.

Malkki, L., i995, Purity and Exile: Violence, Memory and National Cosmology among Hutu Refugees in Tanzania (Chicago: University of Chicago Press).

Manganelli, A., I997, Audizione del direttore del servizio centrale per la protezione dei collaboratori di giustizia, dottor Antonio Manganelli, Commissione parlamentare d'inchiesta sul fenomeno della mafia e delle altre associazioni criminali similari, 7 febbraio I 997 , 9a l.c. eduta.

Marino, L., I992, La verità di piombo. Io, Sofrie gli altri (Milan: Edizioni Ares).

Mauss, M., I903, L'histoire de la confession in V. Karady (ed.), I 969, Oeuvres.Vol.2. Représentations collectives et diversités des civilisations (Paris: Les Éditions de minuit), 640-642.
-, I973, Sociologie et anthropologie (Paris. Presses universitaires de France).

-, 1990 [1925], The Gift. The form and reasons for exchange in archaic societies, trans.W.D. Halls (London: Routledge).

—, 1997, Écrits politiques (Paris: Fayard).

Morucci, V., I 997, 'Intervento'. Commissione parlamentare d'inchiesta sul terrorismo in Italia e sulle cause della mancata individuazione dei responsabili delle stragi, 22 seduta, i 8 June I 997.

Moss, D., I989, The Politics of Leftwing Violence in Italy, 1969-1985 (Basingstoke: Macmillan).

Neppi, Modona, G., i 992, Come ai tempi del terrorismo, La Repubblica, June io, p. I, Iо.

Ormanni, R., i 999, Pentiti d'Italia, uniamoci!, Panorama, 27 May, p. 85.

Padovani, T., i98I, La soave inquisizione: osservazioni e rilievi a proposito delle nuove ipotesi di ravvedimento, Rivista italiana di diritto e procedura penale, II, 529-545.

Parkin, R., I996, The Dark Side of Humanity: The Work of Robert Hertz and its Legacy (Amsterdam: Harwood Academic Publishers).

Peci, P., I980, Caro Dalla Chiesa, se darete retta a me, $L^{\prime}$ Espresso, no. 52, Dec. 28.

-, I983, Io, l'infame (Milan: A. Mondadori).

Prosperi, A., r 997, Pentiti e pentimenti, Una Città, June.

Schwan, G., I998, The 'Healing' Value of Truth-telling: Chances and Social Conditions in a Secularized World, Social Research, 65, 4, 725-740.

Scorti, P., I 985, Il delitto paga? L'affare Tobagi (Milan: Sugarco).

Stajano, C., I982, L'Italia nichilista. Il caso di Marco Donat-Cattin, la rivolta, il potere (Milan: A.Mondadori).

Stille, A., 1996, Excellent Cadavers: The Mafia and the Death of the First Italian Republic (London: Viking).

Stirrat, R. and Henkel, H., i 997, The development gift: the problem of reciprocity in the NGO world, Annals of the American Academy of Political and Social Science, 554, November, 66-8I.

Strathern, M., I988, The Gender of the Gift. Problems with Women and Problems with Society in Melanesia (Berkeley: University of California Press)

Vercher, A., I992, Terrorism in Europe: An International Comparative Legal Analysis (Oxford: Clarendon Press).

Violante, L., I 997, Mafia e società italiana. Rapporto '97 (Bari: Laterza). 